\title{
Managing Sustainable Mangrove Forests in Peninsular Malaysia
}

\author{
Kamaruzaman Jusoff \\ Forest Gespatial Information \& Survey Lab \\ Faculty of Forestry, Universiti Putra Malaysia, Serdang 43400 Selangor, Malaysia \\ Tel: +60-192279507Ｅ-mail: kamaruz@putra.upm.edu.my \\ Dato’ Hj Dahlan bin Hj Taha \\ Deputy Director General (Planning and Development)
}

Forestry Department Peninsular Malaysia, Ministry of Natural Resources and Environment

Forestry Department Headquarters Peninsular Malaysia, Jalan Sultan Salahuddin 50660 Kuala Lumpur, Malaysia

Tel: +60-12-2198069Ｅ-mail: dahlan@forestry.gov.my

The research is financed by Peninsular Malaysia Forestry Department Headquarters and Universiti Putra Malaysia.

\begin{abstract}
Mangrove forests in Peninsular Malaysia are found mainly on the sheltered coasts, estuaries, rivers and some near-shore islands. Mangrove forests support a diverse range of animals and plants and are important breeding ground for a vast array of organisms. The importance of mangrove forests in providing invaluable goods and services both in economics and environmental terms are well understood and documented. Forestry Department Peninsular Malaysia (FDPM) has been keeping abreast with current issues at the national, regional and international levels in managing the mangrove forests. FDPM has always been fully committed to the implementation of the sustainable forest management practices and in line with current concerns such as climate change, conservation of biological diversity and natural calamities including tsunami, have brought about a heightened expectation to the forestry profession. The policy and management of mangrove forests have great impacts on the political, social, economic, ecological and environmental well- being of the country, and thus managing mangrove forests is very challenging to the department. Mangrove forests management system has undergone changes from merely managing for its wood produce, to a management system that incorporates multiple roles, protection and conservation. Systematic management of mangrove forests started as early as 1904, with the adoption of the first working plan for Mangrove Forests in Matang. The Matang mangroves are identified as the best described mangrove forests in the world and is an exemplary of the sustainable managed mangrove forests. The Matang mangroves is in its third ten-year period of the second rotation, and after more than 100 years of management, the forest is still intact, providing sustainable various goods and services. This in itself is a manifestation of the success of forest management practices that aptly earned Matang mangroves as the best managed mangrove forests in the world. Special emphasis to the protection of the mangrove forests is enshrined in the National Forest Policy 1978 (revised1992) and duly recognized and given specific attention in the National Forestry Act 1984 (revised 1993). Future management of mangrove forests in Peninsular Malaysia will adopt an integrated approach by further refining the current management approach and incorporating latest findings and updated information through more vigorous R\&D, scientific expeditions and studies on mangrove forests. A paradigm shift to conserve biodiversity even in the management of production mangrove forests will be emphasized. The National Forestry Policy and other policies related to mangrove forests need to be revised from time to time to match prevailing conditions and requirements, to ensure the realization of its multi-functions in perpetuity. The success in the sustainable management of mangrove forests by FDPM has in fact contributed to the sustainability of the Wetlands in Malaysia which is crucial to the survival and future health of the earth too.
\end{abstract}

Keywords: Sustainable, Mangrove, Management, Malaysia

\section{Introduction}

Mangrove forests forms one of the major wetland types in Peninsular Malaysia, which have been identified as one of the key life support systems on earth. The importance of mangrove forests goes beyond their status as the habitat of many endangered flora and fauna species. Mangrove forests are a valuable natural resource with distinctive diversity, high intrinsic natural productivity and unique habitat value. Mangrove forests provide invaluable goods and services both in economics and environmental terms. Apart from the production of poles, charcoal and fuel wood, the mangrove 
ecosystem supports a wide range of functions such as coastline protection, assimilation of waste, source of food, shelter and sanctuary for fauna, spawning and breeding ground for marine life and also recently proven as a barrier to significantly reduce the height and force of the waves of the tsunami.

Traditionally, the coastal communities living within or at the fringes of the mangrove forests have been dependent on the mangrove forests for their livelihood. Mangrove forests are a major source of fishery resources. The mudflats are habitats for various types of shellfish, where many species of fish, prawns and other marine fauna spawn and feed. Local communities have been relying on the mangrove forests for consumable plants and medicinal herbs. Leaves, buds, fruits, and seeds of some mangrove species are used for human consumption. Some provide a wide range of medicinal uses, such as the bark of Rhizophora, which is used to heal fractures, cure diarrhea and stop hemorrhages.

The mangrove forests can be an idyllic retreat for nature and wildlife lovers, photographers, bird-watchers or anyone who wants to relax and appreciate the beauty of the mangrove environment and its diverse flora and fauna. The mudflats are refueling and roosting sites for large numbers of migratory birds. The riverine areas in the mangroves offer potential for sport fishing. The meandering rivers and rivulets add to the peaceful environment especially to those escaping the tension of city life. Fireflies found at river estuaries, has been a major ecotourism attraction, such as in Kampong Kuantan, Selangor; Kampong Yakyoh, Trengganu; Delta Kelantan, Sungai Lebam, Johore; and Kuala Linggi, Negeri Sembilan/Melaka.

\section{Distribution of mangroves in Peninsular Malaysia}

Mangroves in Peninsular Malaysia are found mainly on the sheltered west coast that borders the Straits of Melaka in the states of Kedah, Perak, Selangor and Johor. Major near-shore islands, including the Kelang islands in Selangor and Pulau Kukup in Johore are also predominantly colonized by mangroves. Small patches of mangrove forests occur along the rocky shores and they include those found in Pulau Langkawi, Kedah; in Pulau Pangkor, Perak; and in Port Dickson, Negeri Sembilan. In the south, mangroves are found in the estuaries of Sungai Pulai and Sg. Johor which drain into the straits of Johor, and the remaining mangroves are found along the straits of Johore. On the east coast, mangrove forests are mostly confined to sheltered estuaries of the Kemaman river in Terengganu, and Bebar in Pahang.

The total area of mangrove forests in Peninsular Malaysia at the end of 2006 is estimated to be 107,802 ha, of which 82,091 ha has been gazetted as Permanent Reserved Forests (PRFs). Perak has the largest mangrove reserves, followed by Johore and Selangor. Mangrove reserves of Matang (Perak), South Johor (Johor) and Kelang (Selangor), together constitute 74 percent of the mangrove forest reserves. Details of mangrove areas by states are shown in Table 1 .

\section{Policy, legislation and prescriptions in managing mangrove forests}

The management of all type of forests including mangrove forests is enshrined in the National Forestry Policy 1978 (revised 1992) (NFP). The NFP was approved by the National Forestry Council in 1977, and later endorsed by the National Land Council in 1978. The Policy lists effective conservation and management of natural forest ecosystems, including the mangroves. It provides guidelines and strong emphasis on the necessity for sound management, conservation, utilization, development and protection of the forests. This commitment is duly recognized and given specific attention by the National Forestry Act 1984 (revised 1993) (NFA). The act provides the legislative backing to the policy and affirms the full protection of the mangrove forests in the PRFs.

Besides these policies and legislation, there are other Federal legislations which complement and support the policies on land use matter. These include the Land Conservation Act 1960, Protection of Wildlife Act 1972, National Park Act 1980, Environmental Quality Act 1974 and Water Enactment 1935.

The need to protect and conserve forest resources is further strengthened and highlighted in the National Economic Recovery Plan 1998. The Plan recommended that mangrove and nipah forests at river estuaries should be classed as Soil Reclamation Forest because of the erosion control function they serve and their sensitivity to disturbance. Meanwhile, the agricultural sector is to target suitable idle lands for development rather than general land clearance practices that deplete natural forests and encroach upon sensitive ecosystems.

As a follow-up to the Earth Summit at Rio de Janeiro in 1992, Malaysia has formulated the National Biodiversity Policy (NBP) which was launched in 1998. The NBP aimed at conserving the country's plants and animal life and creating a safe, healthy and productive environment. In addition, Malaysia has developed a number of sectored policies covering biodiversity such as the National Environmental Policy (NPE), the Third National Agriculture Policy and the National Wetlands Policy. NPE is based on eight inter-related and mutually supporting principles that harmonize economic development goals with environmental imperatives. It was formulated to complement and enhance the environmental dimensions of other existing national policies, such as those on forestry and industry, and takes cognizance of international conventions on global concerns.

The National Physical Plan (NPP), was prepared under the provision of Section 6B of the Town and Country Planning Act 1976 (Act 172). It was approved by the Cabinet on 20th April 2005 and by the National Physical Planning Council 
(NPPC) chaired by the Prime Minister, on the 26th April 2005. The NPP is a long term strategic plan for the period until 2020 that contains written statement formulating strategic policies for the purpose of determining the general directions and trends of the physical development and conservation of Peninsular Malaysia. The NPP is to be the national physical planning guideline and to be implemented by all the states in Peninsular Malaysia. The NPP has classified many parts of mangrove areas as Environmentally Sensitive Areas (ESAs).

The Environmental Quality Act 1974 was amended in 1985 to include Environmental Impact Assessments (EIAs) for forestry activities. The order came into force in 1987, requiring EIAs for activities that involve clearing of mangrove swamps or islands adjacent to national marine parks; conversion of mangrove areas for industrial, housing or agricultural areas covering an area of 50 ha or more; drainage of wetland, wild-life habitat or virgin forest covering an area of 100 ha or more; and land-based aquaculture projects accompanied by clearing of mangrove swamp forests covering an area of 50 ha or more.

In addition, various regulations and guidelines for forest harvesting and related development in mangrove areas have been adopted. These include the 'Forest Harvesting Guidelines in mangrove forests', 'ITTO guidelines on the conservation of biological diversity in tropical protection forest' and the proposed guidelines for conservation and development of ESAs. In the wake of the tsunami at the end of 2004, the government established the 'Special National Task Force on Planting of mangrove and other suitable species in Coastal Areas. This is a multidisciplinary committee with the task including nationwide survey and mapping of the mangrove areas, assessment of suitable sites for permanent reserve forests; rehabilitation and conservation; research, and awareness programs.

\section{International commitments}

Tropical forest and its management had dominated discussions and deliberations at the international level. Mangrove forests, which form one of the major wetland types have gained worldwide recognition. Malaysia is a signatory to various international forest-related agreements which includes the United Nations Forum on Forests (UNFF), Convention on International Trade in Endangered Species of Wild Fauna and Flora (CITES), Convention on Biological Diversity (CBD), United Nation Framework Convention on Climate Change (UNFCCC) and Convention on Wetlands of International Importance especially as Waterfowl Habitat (Ramsar Convention). These agreements have initiated variety of programs and projects to inculcate and institutionalize aspects related to conservation and sustainable use of biological resources.

As a party to the Ramsar Convention, Malaysia undertook to promote wise use and conservation of wetlands and establish nature reserves in wetlands and designate areas as Ramsar sites. With the CBD, Malaysia is committed to formulate national strategies and action plan to integrate conservation of biological diversity into all relevant development. The two prominent CBD decisions are the global strategy for plant conservation and acceptance of ecosystem approach, with the ultimate and long term objective to halt the current and continuing loss of plant diversity. The various international agreements will continue to influence our forest management practices as well as timber trade.

\section{Management of mangrove forests}

Managing mangrove forests has been very challenging. The policy and management have great impact on political, social, economic, ecological and environmental well-being of the country. Forestry Department Peninsular Malaysia (FDPM) holds the responsibility and obligation in managing and safeguarding our mangrove resources. FDPM has taken steps to designate mangrove forest reserves to ensure they are efficiently and sustainably managed. Mangrove forest reserves are managed with the overall goal of conserving and managing the sustainability of forest through sustainable management, and maintaining its important roles in the national economy and environmental stability. Hence, sustaining their ecosystem functions, services and production. This goal was approved by the National Forestry Council through the National Land Council in 1992 and is binding for the states in Peninsular Malaysia.

Mangrove forests management system has changed from merely managing for its wood produce, to a management system that incorporates multiple roles, protection and conservation. Systematic management of mangrove forests started in 1904, with the adoption of the first working plan for Mangrove Forests in Matang. In fact, mangrove forest management proper actually started in 1902, with the first gazettement of mangrove forest reserve.

In early 1960's, there was a gradual change to the uses of the mangrove ecosystem, due to the increasing pressure for coastal land by the growing population, particularly along the west coast of Peninsular Malaysia. Large mangrove areas were excised for residential, agricultural and industrial purposes. These are in direct conflict with the ecologically sound multiple-use management system and prompted an urgent need for the formulation of a national mangrove management plan to ensure rational management and utilization as well as resolving conflicts in resource utilization by the various sectors.

In 1996, the Cabinet issued a directive to avoid further loss of mangroves, urging protection of the coastal areas and to manage the resource on a sustained yield basis. This has also been incorporated into other environmental policies, to maintain the extent and integrity of the mangrove ecosystem and ensure sustenance of the ecosystem functions, services 
and production. The total remaining mangrove forests in Peninsular Malaysia is the result of these initiatives. A good example is Matang mangroves, which has actually increased by 1,498 hectares, as compared to the total area when they were gazetted.

Beside mangroves in PRFs, there are stateland and alienated mangroves. Even though the areas are mostly small and fragmented, their combined acreage nevertheless are quite substantial. Steps must be taken to gazette the stateland mangroves as PRFs, in line with the call made by the $19^{\text {th }}$ meeting of the National Forestry Council, chaired by the Deputy Prime Minister in 2005.

Mangrove forest reserves are divided into four broad classifications as provided for in the NFP. They are:

(a) Protection Forest for ensuring favorable climatic and physical conditions of the country , safeguarding of water resources, soil fertility, environmental quality, conservation of biological diversity and the minimization of damage by floods and erosion to rivers and agricultural land (ha).

(b) Production Forest for the supply in perpetuity at reasonable rates of all forms of forest produce which can be economically produced within the country and are required for agricultural, domestic and industrial purposes. as well as for export (ha).

(c) Amenity Forest for the conservation of adequate forest areas for recreation. Eco-tourism and in promoting public awareness in forestry (ha).

(d) Research and Education Forest for the conduct of research, education and conservation of biological diversity (ha).

\section{Mangrove management and conservation by various state forestry departments}

As land is a state matter, mangrove forests are managed within the exclusive jurisdiction of the respective state forestry departments. This resulted in slight differences in terms of management regimes, objectives, priority and needs between states. Mangrove forests management and conservation by the various state forestry departments are discussed in the following paragraphs.

\subsection{Matang mangroves, Perak}

Matang mangroves is one of the earliest forest to be gazetted as Permanent Forest Reserve, and subsequently managed on a systematic and sustainable approach since 1904. The Mangrove forests stretches from Kuala Gula in the north to Panchor in the south, covering a distance of about $52 \mathrm{~km}$ and $13 \mathrm{~km}$ wide. The extent of Matang mangroves is 40,466 hectares, though small in terms of hectarage, the roles has extended beyond the traditional role of producing timber to include tourism, bird sanctuary, research and education, preservation of unique sites, conservation and environmental stability. Matang mangroves not only provided a constant yield of renewable forest products, but also forestry resources and a conducive environment for aquaculture. Matang mangroves hosts 34 permanent settlements of which 28 are fishing villages with a total 5,300 households and an estimated population of 31,800 who are mainly engaged in mangrove activities. These villages are located inside, within and along the periphery of Matang Forest Reserves.

Matang mangroves is divided into 3 ranges: Kuala Sepetang, Kuala Trong and Sungai Kerang, comprising 19 forest reserves and a total of 108 compartments. Reservation started in 1902, but the whole of Matang Mangroves was finally gazetted in 1906. The first written working plan of Matang Mangroves was prepared by A.E. Wells in 1904, which was more of a scheme to control and regulate felling. The management system of Matang mangroves has been subjected to many changes. The first system applied was the minimum girth system, which was then replaced by the standard system. Later the shelterwood system was proposed, with the provision of the retention of standards which was later replaced by the provision of the two-staged final felling. Similarly, the rotation length was reviewed from 20 years to 30 years, then to 40 years and finally back to 30 years in 1950 . The 30 years rotation was based on report (Noakes, 1952) that the Mean Annual Increment of trees in the sample plot culminates at age 23 years.

In the early years, the period for each working plan has been short and structured. The first 10-year working plan of Matang Mangroves only started in 1930, for the period 1930 to 1939. This working plan was periodically revised incorporating changing circumstances and the availability of new findings. During the early years, the working plan has been successfully prepared to maximize the sustained yield of wood production through only one silviculture system with limited production for non wood and other forest services. Matang mangrove has a dynamic silvicultural system, which has undergone refinement from time to time. Silvicultural operations are modified to suit the individual forest types. With the availability of more information through various research work, expeditions and many other related study, the scope of the working plan has been extensively expanded to include the application of compatible silvicultural system to the specific ecological types, which have been grouped into the respective productive and protective management zone. The functional role of Matang mangrove was then extended beyond the traditional role of producing timber to include ecotourism, wildlife sanctuary, education, research, preservation of unique sites and other biodiversity conservation. 
The latest revision to the management plan covered the period 2000-2009, which emphasized on an integrated approach of management, considering on a comprehensive assessment of all direct benefits derived from the mangrove forests. Under this plan, Matang mangroves are divided into four management zones, namely (i) protective zone (7,360 ha), (ii) restrictive protective zone (2,892 ha), (iii) productive zone (29,794 ha) and (iv) the unproductive zone (420 ha) (Razani et al, 2007). The yield at final felling was estimated to be 179 tonnes/ha, which represented an increase of 2 tonnes/ha and 4 tonnes/ha from the previous management plan period, 1980-1989 and 1990-1999, respectively. The ecological consideration provides the basis and option to tap the full potential of the forest resources. Zoning represents a broad application of the concept of multiple uses, involving designation of forest areas for specific functional purposes.

After more than a century of continuous and systematic management, Matang mangroves have only lost 250 hectares to settlement expansion and infrastructure facilities. As compared to other mangrove areas in the country, Matang mangroves has never been excised for agriculture or aquaculture activities. On the other hand, there was a net gain of 1,498 hectares over the years, with excision and accretion going on at the same time.

The success of Matang mangrove is due to the strong commitment, policy and legal framework, professional forest management, increased public awareness, and linkages with local institutions of higher learning and research organizations. Future strategy of managing mangroves in Perak will adopt an integrated approach by further refining the current integrated approach to mangrove forests which will enhance their sustainable economic, social and environmental benefits with new strategies incorporating the latest findings and updated information gained through various research works, continuous specialized scientific expeditions and many other studies on the existing mangroves.

\subsection{Johore mangroves}

Johor is dominated by coastal plains and large low-lying wetland areas. The districts of Pontian, Kota Tinggi and Johor Bahru share almost all the state's mangrove forests, while Batu Pahat, Muar and Mersing share a minor portion. Sg. Pulai is the most important in terms of production of poles and charcoal, followed by Sg. Johor. Reservation of mangrove forests in Johor started in 1923 with the gazette of Sg. Pulai and Pulau Kukup forest reserves. Management of mangrove forests has undergone three management Period, early management (1941-1972), management after 1972 (1972-1999) and current management (after 2000). The first Working Plan was prepared by F.S. Walker in 1941, but was only implemented in 1947, after the $2^{\text {nd }}$ World War. The objective then was to supply charcoal and firewood to Singapore as well as marketed locally. Stick thinning was introduced using sticks up to 16 feet $(4.9 \mathrm{~m})$ in length. The practice was later abandoned due to heavy branching, as the forest was then managed for the production of poles. Another working plan was introduced by P.F. Burgess in 1950 which was subsequently revised in 1955 and 1960.

After 1972 another working plan was drafted by Clarke with the objective of protecting coastal areas, provide employment for the locals and production of firewood, charcoal, poles and piling on a sustained yield basis. The silvicultural system adopted by Clarke was a 20-year rotation crop based on clear felling with one intermediate thinning at year 15 using the stick thinning method with a spacing of 1.6 metre. Buffer zone along rivers was recommended to be not less than 20 metre from the low tide mark.

The current management plan for the mangroves of Johore (2000-2009) is an output of a two-year project carried out by the FDPM, the state Forestry Department of Johore and the Danish Cooperation for Environment and Development (DANCED). The plan provides long term management planning and guidelines on conservation and protection, rehabilitation of degraded sites, maintaining the ecological functions of mangroves as feeding and breeding ground of coastal fauna, and setting aside adequate forest for community and amenity purposes, research and training. It has four main components: Bio-D Conservation, Sustainable Mangrove Production, Community Forestry and Awareness and Recreation.

Under the current management plan, the mangrove forests are managed with a system of clear felling and a rotation of 20 years based on area control. No thinning or intermediate felling are carried out. The area laid out for production constitutes some 8,183 ha or $46 \%$ of the total extent of the mangrove forest reserves. Allocation of areas for harvesting is based on the annual coupe of 400 ha. (300 ha. in Sg. Pulai and 100 ha. in Sg. Johor Forest Reserves). Based on a 20-year rotation, the area to be harvested within the ten year planning period is 4,092 ha. Thus, approximately 400 ha or $5 \%$ of the total productive forests (2.3\% of the total mangrove forest reserves) are clear felled, annually. As a precautionary measure, areas for felling are spread out to ensure minimum disturbance to the habitat and wildlife have ample opportunity to consolidate into the adjoining forested areas. The harvested areas are ensured total regeneration either through natural, artificial or combination of both.

Areas other than the production forests are to be designated as Old Growth Forests, Coastal Protection Forest, River Bank/Riparian Protection Forest and Wildlife Refuge Forest. They may serve one or a multiple of overlapping functions. The scattered compartment of old growth forests are valuable conservation sites that provide nesting sites for large birds. Most of the Old Growth Forests are in Sg. Johor Forest Reserve, and the state forestry department is currently identifying these areas to be designated by compartment. One Virgin Jungle Reserve (VJR) was established in Kuala 
Sedili Forest Reserve and one amenity forest established in Sg. Johor Forest Reserve. In addition, two State Parks were established by the Johor National Parks Corporation. They are located at Tg. Piai (Sg. Pulai Forest Reserve) and Pulau Kukup. Three mangrove areas were declared as Ramsar Sites, viz. Pulau Kukup, Sg. Pulai Forest Reserve and Tg. Piai. Additional sites identified are the Kuala Sedili Forest Reserve, Sungai Lebam, Sungai Santi and Sungai Sebana.

\subsection{Selangor mangroves}

Mangrove forests of Selangor are mostly found in Klang islands, Banjar Utara and Banjar Selatan. The total mangrove area under PRFs is 14,897 ha, which is about 6\% of the total PRFs of Selangor. The first working plan for Selangor mangrove was prepared by A.E.Sanger for the period 1922 to 1925. Between 1921 and 1961, seven working plan have been prepared for Selangor mangroves. Since 1962, mangrove forests of Selangor were managed under the Annual Felling and Treatment Plan. They are managed for the production of quality poles, firewood, fishing stakes and piling poles, and at the same time sufficient areas are set aside for conservation and protection.

Selangor mangrove was first managed under a rotation of 30 years with intermediate felling at 20 years. The rotation was then changed to 40 years, then back to 30 years, then to 20 years and finally 15 years. The change in rotation was due to changes in the primary management objectives from production of firewood and charcoal to that of poles. At 20 years rotation, the intermediate felling was conducted at 15 years. Further reduction of rotation to 15 years was due to the high demand for poles and the market has adjusted to accept smaller size poles. This also has economic and silvicultural reasons, to maximize the number of poles produced per ha, to cater for the short fall in the annual supply as mangrove productive areas were further reduced (Nik Mohd Shah et al, 2005). Currently, based on a productive area of $8,760 \mathrm{ha}$, and a rotation age of 15 years, the annual coupe is fixed at 578 ha per year. With an average of 3,000 poles per ha. from the first intermediate felling and 2,500 poles per ha form final felling, the estimated production of poles from Selangor mangroves is about 2,750,000 pieces annually.

The silvicultural system of Selangor mangroves has evolved around the minimum girth system, shelter-wood system and clear felling. The shelter-wood and minimum girth system was favored in the past, when the rotation age was longer and natural regeneration was plentiful. As the rotation age was shortened to half, more areas need to be rehabilitated artificially. Currently, the average size of areas requiring rehabilitation ranges between $15-20 \%$ of the annual coupe. The main species used for rehabilitation are the highly productive Rhizophora apiculata and to a lesser extent the R.mucronata.

\subsection{Kedah mangroves}

The largest mangrove forests of Kedah is the Merbok Mangrove Forest Reserves that covers an area of approximately 4,085 hectares. The remaining mangroves are located in Pulau Langkawi (3,116 hectares), comprising of three large mangrove areas. They are Kampong Kuala Isap-Gua Cerita mangroves, the Sungai Ayer Hangat-Kubang Badak mangroves and the Pulau Dayang Bunting-Pulau Tuba mangroves. Mangrove forests in Kedah has shrunk over the years due to land demand for development, agriculture and aquaculture projects. The Bukit Malut mangrove with a total area of 110 hectares has given way to aquaculture ponds, while another 975.79 hectares of Sungai Merbok Forest Reserve was converted to make way for aquaculture ponds, small industries and other development projects.

The mangrove forests management plan for Kedah was prepared with the objectives: to ensure sustain supply of timber resources for local industries; to produce poles for local users; and to conserve and protect coastal and fringes areas from erosion, rough current and winds. The concept of management is minimal interference, conservation and minimal silvicultural treatment. The annual coupe is 100 hectares on a 30 years felling rotation. Harvesting of mangrove forests is only restricted to Sg. Merbok area, while the mangroves of Langkawi are managed for conservation, ecotourism and protection. However, harvesting of mangroves for its timber is becoming less common in Kedah.

\subsection{Trengganu mangroves}

The mangroves of Trengganu are mostly small and fragmented covering a total area of 2400 hectares. They are mainly limited to protected waters of estuaries and lagoons. With a small total area, they are limited in resource yield. Nevertheless, they play uniquely important ecological and protective functions. The largest mangrove area is the Kemaman Forest Reserve with a total area of 938 hectares. The next largest mangrove area is the stateland mangrove in Setiu district, stretches from Merang in the north to Kampong Raja, Besut. These are mostly fringing mangroves consisting mostly of Nypa and some stand of Rhizophora.

Forestry activities is less common than fishing in Trengganu mangroves. The charcoal industri in Trengganu is working under constraints capacity. The extraction of mangrove timbers for poles and scaffolds are very much localised. Mangroves are seldom exploited commercially for its timber, but more for own consumption by local villages. It is common to see fish traps such as bubu, made of mangrove timber in Trengganu. The main fishing activities in mangroves are crab trapping, net trapping and shellfish harvesting. These activities are merely part time, particularly during the Northeast monsoon season between October and January. Waterways fronting or surrounding the mangroves are suitable for marine cultures such as cage culture for fishes and rafts culture for oysters and mussels. 
Although the mangroves in Trengganu are not exploited commercially for timber, but they are subjected to conversion into development and industrial area. Much of the mangrove areas around Kuala Trengganu has been converted, leaving some remnants at Sungai Ibai, Sungai Trengganu and the lagoon wetland area at Batu Rakit. The Forestry Department is taking the initiatives to rehabilitate the remaining degraded mangrove areas in Trengganu

\subsection{Other mangroves}

Mangrove forests are also found in the other states of Peninsular Malaysia. However, these mangrove forests are scattered, small in extent, not economically significant yet but ecologically and environmentally important. These areas are briefly summarized in Table 2 .

\section{Issues in managing mangrove forests}

The mangrove ecosystem is a sensitive ecosystem that has continued to be affected by the rapid economic growth of the country. The familiar development-environment frictions have always been a major concern. Population pressures and the increasing demand for land continue to pose threat to the coastal and marine resources. Mangrove forests have been the most vulnerable, under severe pressure and the first to be cleared when the need for land arises. There have been perceptions that mangrove areas are considered wasteland, thus, converting mangrove to other uses will fetch a higher financial returns. To many, mangroves are considered an eyesore that need to be cleared, while to some, mangroves are a waterfront that need to be developed, failing to recognize the essential functions of mangroves in maintaining the coastal ecosystem.

There is limited information or documentation on mangrove destruction. Similarly, many statements have been made about the impact on biological diversity loss, but there are lack of scientific data or evidence to support these statements. However, shrinking mangrove areas resulting from developmental decisions of the past, as well as signs of strain on the remaining mangroves provides evidence of threat to this ecosystem.

Being a fragile ecosystem, mangroves tend to fluctuate as a result of slight changes in the natural environment. Rapid development has led to clearing of mangrove areas to make way for urban and infrastructure development, beach resorts and aquaculture ponds. Industries and factories situated near the rivers and streams might discharge their effluent into the water systems, polluting and choking the riverine habitat, and eventually adversely affecting the aquatic biodiversity. The disruption of mangrove functions as part of our wetland ecosystem has a high cost: economically, socially and ecologically. The disturbance of their natural balance can destroy critical gene pools required for medical and agricultural purposes, affecting their ability to protect the coastline naturally and ruined their use for educational and recreational purposes. Constant sedimentation has endangered a variety of fishes and other marine species, particularly the corals. Destruction of mangroves led to a dramatic loss to the commercial and recreational fishing industry, coastal erosion, and endangered many floral and faunal species.

Another issue is jurisdiction between federal and state government. Matters related to land use and natural resources remains within the exclusive jurisdiction of the state. The vast natural resources sectors such as forests, fishery, wildlife, mining and agriculture are under different agencies/authority with separate sets of regulatory laws, which at times creates overlaps in prescriptive and enforcement jurisdiction. The establishment of the National Forestry Council has successfully tackled this issue at policy level, and the various committees formed at the federal and state levels has helped to further improve towards conservation, sustainable use, management and development of the mangroves.

Public awareness regarding mangroves and their conservation is on the rise. But some still do not appreciate the role of mangroves to the environment and quality of life. Despite the many benefits and functions, mangroves is seen not much more than timber, charcoal and woodchips, Indirect benefits offered by mangroves are easily forgotten and set aside when quick profits can be generated by converting mangroves to other uses. Absence of proper evaluation on mangrove forests results in the undervaluation of the mangrove forests. This in turn, has sent the wrong signals to the market. Therefore, there is need for a comprehensive valuation of our mangrove forests. More applicable inputs from research are needed.

\section{Future strategy in managing mangrove forests}

FDPM have been successful in managing and conserving the mangrove forests in Peninsular Malaysia since the early 1900s. However, there is room for further improvement. The NFP and other related policies will be revised from time to time to match prevailing conditions and requirements, and to ensure the realizations of its multi-functions in perpetuity. The co-operation and co-ordination of relevant agencies will be fostered with respect to specific objectives in safeguarding the mangrove ecosystems. The aspirations and concerns of other related policies adopted would be viewed and considered in perspective so that a holistic approach in resource management and development could be amicably achieved.

Future management of mangrove forests in Peninsular Malaysia will continue to adopt an integrated approach by further refining the current management approach and incorporating latest findings and updated information through 
more vigorous R\&D, scientific expeditions and studies on mangrove forests. The remaining mangrove forests will be protected to ensure its biological diversity remained intact and not lost in the name of development. Disruption to the mangrove ecosystems and functions must cease, the diversity of remaining mangroves must be retained, and where possible rehabilitation, restoration and re-creation of mangroves habitats must continue to be pursued.

Synergetic public-private partnership will be forged to ensure a functional coordination among concerned agencies. Public awareness and education related programs will be further enhanced. Efforts will be intensified in creating a better understanding among the public and policy makers on the importance of mangroves to the environment.

\section{Conclusions and Recommendations}

FDPM recognizes the significant role of mangroves as an integral part of a wider forest ecosystem. FDPM is fully committed to ensure that our mangrove resources are sustainably managed, utilized and preserved for the benefits of present and future generations. From the first management plan, FDPM have moved forward and took a more positive approach by giving increasing emphasis on the conservation aspects of mangroves forest management. The role of foresters has changed from merely dealing with traditional forestry tasks to a multi-task approach. The practice of sustainable forestry production has contributed not only economically but also socially and environmentally. Matang mangroves is a living exemplary of the forest management practices that also conserves the biodiversity. The many diverse flora and fauna of the mangrove forests that are still intact are proof of our good management and conservation effort. The success in the sustainable management of mangrove forests by FDPM has in fact contributed to the sustainability of the Wetlands in Malaysia which is crucial to the survival and future health of the earth too.

\section{References}

Nik Mohd Shah, N. M., Shah Rani, A. Z. and Zakariah, A. H. (2005). Management and conservation of mangroves: Selangor Experience. In: Shaharuddin, M. I., Azahar, M., Razani, U., Kamaruzzaman, A. B., Lim, K. L., Suhaili, R., Jalil, M. S. and Latiff, A. Forest Biodiversity Series 4: Sustainable Management of Matang Mangroves: 100 Years and Beyond. Forestry Department Peninsular Malaysia. pp 91-101.

Noakes, D.S.P. (1952). A Working Plan for the Matang Mangrove Forest Reserves, Perak. Forestry Department. Federation of Malaysa. 172 pp.

Razani, U. and Abdullah Sani, S. (2005). Matang forest reserve: Best managed mangrove forests in the world. Pap0er presented at the National Conference on the management and conservation of forest biodiversity in Malaysia. 20-21 March, 2007. Putrajaya.

Table 1. Current extent (ha) of mangrove forests (PRFs and Stateland) in Peninsular Malaysia (2006)

\begin{tabular}{|l|l|l|l|}
\hline State & Mangrove Forest Reserves & Stateland Mangroves & Total \\
\hline Johor & 16,127 & $13,561^{*}$ & 29,688 \\
Kedah & 6,202 & 1,916 & 8,118 \\
Kelantan & - & 744 & 744 \\
Malacca & 80 & - & 80 \\
N. Sembilan & 204 & - & 204 \\
Pahang & 2,387 & 1,813 & 4,200 \\
Penang & 376 & 494 & 870 \\
Perak & 40,466 & 1,885 & 42,351 \\
Perlis & - & 13 & 13 \\
Selangor & 14,897 & 4,650 & 19,547 \\
Terengganu & 1,295 & 692 & 1,987 \\
\hline Total & 82,091 & 25,768 & 107,802 \\
\hline
\end{tabular}

*Mangrove areas (including mudflats) that has been approved by the state government in 2005 to be gazetted as

PRFs 
Table 2. Other mangrove forest areas found in Malaysia

\begin{tabular}{|c|c|}
\hline State & Mangrove forests \\
\hline Pahang & $\begin{array}{l}\text { There are a total of 4,200 ha. of mangrove forests, found in the forest dictrict of Rompin and } \\
\text { Kuantan, of which 2,387 ha have been gazetted as PRF. }\end{array}$ \\
\hline Perlis & e forests are found in patches in Kuala Perlis area. \\
\hline Kelantan & $\begin{array}{l}\text { There are patches of mangrove forests at estuaries and their river banks at Tumpat, Pasir } \\
\text { Puteh and Bachok districts. A centre of excellence was established in Delta Kelantan }\end{array}$ \\
\hline $\begin{array}{l}\text { Negeri } \\
\text { Sembilan }\end{array}$ & $\begin{array}{l}\text { Much of the mangrove forests found in the vicinity of Port Dickson has been developed for } \\
\text { resorts, marinas and housing }\end{array}$ \\
\hline Malacca & Mangroves found on river banks and estuaries for conservation. \\
\hline Penang & $\begin{array}{l}\text { Mangrove forests cover a total area of } 967 \text { ha, of } 376 \text { ha gazetted as PRF and } 600 \text { ha in } \\
\text { alienated and state land. Centre of excellence for Nipah established in Hutan Simpan Ayer Hitam } \\
\text { Dalam. }\end{array}$ \\
\hline
\end{tabular}

